\title{
FAKTOR - FAKTOR YANG BERHUBUNGAN DENGAN RENDAHNYA CAKUPAN IMUNISASI MR (MEASLES RUBELLA) PADA BALITA
}

\section{WILDA WAHYUNI SIREGAR ${ }^{1}$, RINA PURNAMA NASUTION ${ }^{2}$, NITA TRIANA SARAGIH ${ }^{3}$, DIAH EVAWANNA ANUHGERA ${ }^{4}$}

\author{
Institut Kesehatan Medistra Lubuk Pakam \\ Jl.Sudirman No.38 Lubuk Pakam \\ e-mail :wilda09wahyuni@gmail.com
}

DOI $10.35451 / j k k . v 3 i 2.682$

\begin{abstract}
Measles and rubella is infectious diseases caused by measles virus and rubella transmitted through the respiratory tract. Measles and rubella highly contagious, and transmitted through splash sneezing or cough. Children who have never got measles and rubella immunization, or who have never had measles and rubella is the high risk of contracting the disiase.This study aims to know the factors related to the low coverage measles, rubella on toddler in the village of Simpang Tiga Pekan district Perbaungan district Serdang bedagai Year 2019. Research used in this study is deskritif quantitative by using the design of cross-sectional. Population in this study is around the mother that has a toddler 9 -59 months are in the village of Simpang Tiga Pekan. Sampling is done by techniques accidental sampling by the number of samles as much as 36 respondents. Research instruments by using the quetionnaire. Data were analyzed by univariate, bivariate with the chi-square test at level 95\%, $a=5 \%$. confidence. Analysis shows that there relationship knowledge mother by administering immunization MR (Measles, Rubella) with 95\% $(a=0,05) p$ value $=0,000$ confidence level, that there relationship attitude mother by administering immunization MR with $95 \%$ (a $=0,05) p$ value $=0,000$ confidence level, that there relationship resources mother by administering immunization MR with $95 \%(a=0,05) p$ value $=$ 0,000 confidence level. Suuggested to mothers should always come at activities posyandu and do immunization regularly and active role in the activities of immunization and search for related information immunization in toddlers.
\end{abstract}

Keywords: knowledge, attitudes, resources, immunization MR

\section{PENDAhUlUAN}

Salah satu kegiatan pelayanan kesehatan yang dicanangkan oleh pemerintah guna menurunkan angka kesakitan, kecacatan bahkan sampai pada kematian khususnya pada balita yakni melalui program imunisasi. Melalui program ini akan meningkatkan kekebalan tubuh secara aktif. Program yang dilaksanakan ini bukan tanpa tujuan yang jelas. Terdapat tujuan jangka pendek dan jangka panjang. Tujuan jangka pendeknya yakni pencegahan penyakit secara individu/kelompok sedangkan yang bersifat jangka panjang pemberian imunisasi ini yaitu 
meniadakan suatu penyakit (Ponidjan, 2012).

Penularan penyakit campak dan Rubella diyakini melalui saluran pernafasan yang ditularkan oleh virus campak dan rubella itu sendiri (IDAI, 2017). Anak yang beresiko tinggi tertular penyakit campak dan rubella adalah anak yang sama sekali belum pernah memperoleh imunisasi campak dan rubella, atau yang belum pernah terinfeksi penyakit ini (WHO, 2017).

Strain Edmonson merupakan jenis antigen yang dipakai dalam imunisasi MR (Measles, Rubella). Pemberian vaksinasi dilakukan bersamaan dan perlindungan terhadap kedua penyakit dapat dilakukan dalam waktu yang bersamaan (Hidayat, 2008)

Pada tahun 2020 pada kegiatan Global Vaccine Action Plan (GVAP) telah ditargetkan bahwa campak dan rubella merupakan penyakit yang menjadi sasaran penting untuk dituntaskan. Selaras dengan hal tersebut The Global Measles \& Rubella Strategic Plan 2012-2020 juga telah membuat perencanaan dimana tujuan akhir yakni mencapai dunia tanpa campak. Dari kegiatan tersebut diperoleh bahwa pemberian vaksin measles dan rubella akan mempertahankan tingkat kekebalan masayarakat yang tinggi dan vaksin terbuat diberikan secara bersamaan dan dievaluasi secara rutin dengan harapan cakupan yang tinggi yakni $>95 \%$ (Ditjen P2P, 2017).

Setiap tahunnya di Indonesia dilaporkan bahwa lebih dari 11.000 kasus suspect campak dan berdasarkan hasil konfirmasi laboratorium, diperoleh 12-39\% campak pasti (lab confirmed) sedangkan $16-43 \%$ adalah rubella pasti (Ditjen P2P, 2017). Diprediksi Sampai dengan tahun 2015 akan terdapat 23,164 kasus campak dan 30,463 kasus rubella. Menelisik kasus yang tidak terlaporkan, jumlah kasus ini seperti gunung es diperkirakan masih banyak kasus yang terjadi di lapangan (Ditjen P2P, 2017).

Berdasarkan Laporan Dinas Dinas Kesehatan Kabupaten Serdang Bedagai Tahun 2018 adapun provinsi dengan cakupan imunisasi MR terendah antara lain Aceh, Sumatera Barat, Sumatera Utara dan Riau. Targetnya, 395 Kabupaten/Kota bisa mencapai 95\% cakupan imunisasin MR yang kondisinya saat ini baru 102 Kabupaten/Kota. Dari data Kabupaten Serdang Bedagai total cakupan MR $65,9 \%$, menunjukan data yg di bawah indikator 95\%. Berdasarkan data Puskesmas tahun 2018 Desa Simpang Tiga Pekan memiliki cakupan imunisasi MR pada Balita sebesar $60 \%$, dan pada tahun 2019 terdapat peningkatan sebesar $65 \%$, hasil ini juga masih menunjukan data yang dibawah indikator 95\%.

Berdasarkan survey yang dilakukan di Desa Simpang Tiga Pekan didapatkan balita yang mendapat imunisasi MR (Measles, Rubella) pada tahun 2019 berkisar $65 \%$, dari data tersebut masing terdapat $35 \%$ balita yang belum mendapatkan imunisasi MR atau berkisar 215 orang. Berdasarkan latar belakang dan temuan masalah tersebut peneliti tertarik untuk mengangkat judul penelitian yakni "Faktor-Faktor Yang Berhubungan Dengan Rendahnya Cakupan MR (Measles, Rubella) Pada Balita Di Desa Simpang Tiga Pekan Kecamatan Perbaungan Kabupaten Serdang Bedagai. 


\section{METODE}

Penelitian ini menerapkan desain penelitian deskriptif dengan pendekatan cross sectional. Lokasi Penelitian dilakukan di desa Simpang Tiga Pekan kecamatan Perbaungan kabupaten Serdang Bedagai dengan populasi semua ibu yang memiliki balita 9-59 bulan yang berada di desa Simpang Tiga Pekan. Pengambilan sampel dilakukan dengan teknik Accidental Sampling dengan jumlah sampel sebanyak 36 responden. Pengumpulan data menggunakan kuesioner dan analisis bivariat melalui uji chi-square dengan tingkat derajat kepercayaan $95 \%$ dan a sebesar 0,05

\section{HASIL}

Karakteristik ibu balita di Desa Simpang Tiga Pekan Kecamatn Perbaungan Kabupaten Serdang Bedagai dapat dilihat pada tabel 3.1 dibawah ini :

\begin{tabular}{|c|c|c|c|}
\hline & \multicolumn{3}{|c|}{ Kecamatan Perbaungan } \\
\hline & \multirow{2}{*}{ Karakteristik } & \multicolumn{2}{|c|}{ Jumlah } \\
\hline No & & Frekuensi (n) & Persentase (\%) \\
\hline 1 & Umur & & \\
\hline & 1. 25-30 tahun & 18 & 50 \\
\hline & 2. $31-35$ tahun & 11 & 27,77 \\
\hline & 3. $36-45$ tahun & 7 & 19,44 \\
\hline 2 & Pendidikan & & \\
\hline & 1. $\mathrm{SD}$ & 9 & 25 \\
\hline & 2. SMP & 15 & 41,66 \\
\hline & 3. SMA & 8 & 22,22 \\
\hline & $\begin{array}{l}\text { 4. Perguruan } \\
\text { Tinggi }\end{array}$ & 4 & 11,11 \\
\hline 3 & Pekerjaan & & \\
\hline & 1. Bekerja & 13 & 36,11 \\
\hline & 2. Tidak bekerja & 23 & 63,88 \\
\hline
\end{tabular}

Berdasarkan tabel di atas dapat ditelaah bahwa dari 36 responden sebagian besar berumur 25-30 tahun sebanyak 18 responden (50\%), berdasarkan pendidikan responden mayoritas berpendidikan SMP sebanyak 15 responden $(41,66 \%)$ dan berdasarkan pekerjaan dapat dilihat bahwa dari 36 responden diperoleh responden yang tidak bekerja yaitu sebanyak 23 responden $(63,88 \%)$.

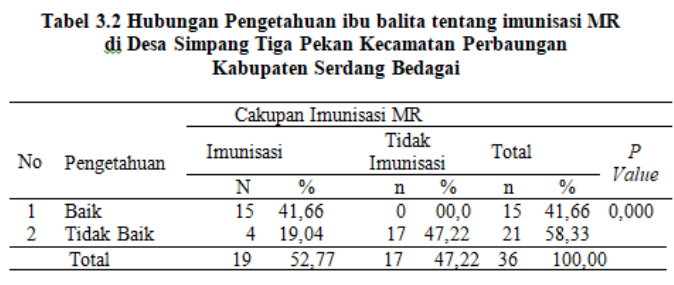

Dari tabel 3.2 dapat dilihat bahwa dari 15 orang responden yang memiliki pengetahuan baik, seluruh balitanya diberikan imunisasi MR. Sedangkan dari 21 orang responden yang memiliki pengetahuan tidak baik didapatkan 4 responden $(19,04 \%)$ imunisasi, dan 17 responden $(80,95 \%)$ tidak imunisasi.

Hasil analisis untuk mengetahui hubungan pengetahuan dengan rendahnya cakupan imunisasi MR didapatkan nilai $\mathrm{p}=0,000$. Berarti $\mathrm{p}$ value < 0,05, maka ada hubungan pengetahuan dengan rendahnya cakupan imunisasi MR pada balita di Desa Simpang Tiga Pekan Kecamatan Perbaungan Kabupaten Serdang Bedagai.



Dari tabel 3.3 dapat dilihat bahwa dari 17 orang responden yang memiliki sikap positif didapat seluruh balitanya diimunisasi yaitu 17 responden $(80,95 \%)$. Sedangkan dari 19 orang responden yang memiliki sikap negatif didapatkan 17 responden (80,95\%) tidak imunisasi, dan 2 responden $(10.52 \%)$ tidak imunisasi.

Hasil analisis untuk mengetahui hubungan sikap dengan rendahnya cakupan imunisasi MR didapatkan nilai $p=0,000$. Berarti $p$ 
value < 0,05, maka ada hubungan pengetahuan dengan rendahnya cakupan imunisasi MR pada balita di Desa Simpang Tiga Pekan Kecamatan Perbaungan Kabupaten Serdang Bedagai.

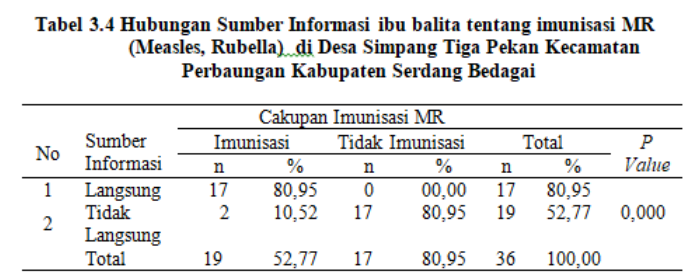

Dari tabel 3.4 diperoleh bahwa dari 17 orang responden yang mendapatkan sumber informasi langsung didapatkan seluruh balita mendapatkan imunisasi MR. Sedangkan dari 19 orang responden yang tidak mendapatkan sumber informasi langsung didapatkan 17 responden $(80,95 \%)$ tidak imunisasi, dan 2 responden $(10,52 \%)$ imunisasi.

Hasil analisis untuk mengetahui hubungan sikap dengan rendahnya cakupan imunisasi MR didapatkan nilai $p=0,000$. Berarti $p$ value $<0,05$, maka ada hubungan sikap dengan rendahnya cakupan imunisasi MR pada balita di Desa Simpang Tiga Pekan Kecamatan Perbaungan Kabupaten Serdang Bedagai.

\section{PEMBAhASAN}

Kurangnya pengetahuan ibu balita tentang imunisasi MR di Desa Simpang Tiga Pekan Kecamatan Perbaungan yang diperoleh dari hasil wawancara. Mayoritas mereka belum mengetahui imunisasi MR karena ini merupakan imunisasi yang baru dikampanyekan pada bulan Agustus September 2018. Menurut Notoatmodjo 2003, pengetahuan adalah hal penting pada proses terbentuknya perilaku seseorang. Pengetahuan merupakan hasil/reaksi yang diperoleh setelah seseorang melakukan pengindraan terhadap sesuatu obyek melalui apa yang dilihat, didengar dirasa dan diraba.

Vaksin MR ini akan menggantikan vaksin campak yang selama ini diberikan pada imunisasi rutin. Vaksin ini merupakan vaksin hidup yang dilemahkan. Terkandug 1000 CCID50 virus campak dan 1000 CCID50 virus rubella pada setiap dosis vaksin MR. Vaksin MR tergolong vaksin yang aman dan efek samping yang umumnya timbul setelah penyuntikan demam ringan dan nyeri pada daerah penyuntikan. Dalam 1 vial terdapat 10 dosis vaksin MR. Melalui pemberian imunisasi MR ini anak akan terlindungi dari kecacatan dan kematian yang diakibatkan oleh berbagai penyakit seperti diare, pneumonia, kerusakan pada otak, tuli, buta pada mata bahkan penyakit jantung bawaan.

Sikap positif sejalan dengan perilaku yang baik. Sikap merupakan reaksi atau respon yang ditimbulkan seseorang yang masih tertutup terhadap suatu objek. Sikap belum merupakan tindakan atau aktifitas, melainkan suatu predisposisi perilaku (Notoatmodjo, 2012). Pada penelitian ini diperoleh bahwa dari 17 ibu yang tidak melaksanakn imunisasi MR pada anaknya memiliki sikap negatif.

Hasil penelitian ini juga sejalan dengan Lailan Najah (2017) yang berjudul Tingkat Pengetahuan Ibu Tentang Imunisasi Tambahan MR (Measles, Rubella) Pada Balita Di Puskesmas Kotagede I Yogyakarta Tahun 2017, mendapatkan ibu dengan tingkat pengetahuan baik lebih banyak melakukan imunisasi tambahan MR, dari pada ibu yang sikapnya kurang.

Sumber informasi merupakan salah satu faktor penyebab rendahnya cakupan imunisasi MR pada balita di Desa simpang Tiga 
Pekan. Informasi adalah suatu pesan yang diberikan/disampaikan oleh komunikator (pemberi pesan) kepada komunikan (penerima). Pada intinya isi pesan yang disampaikan oleh komunikator dapat diterapkan oleh komunikan melakui perilaku atau tindakan secara positif dan aktif (Notoatmodjo, S. 2003).

Imunisasi Paling banyak MR tidak diberikan di wilayah desa Simpang Tiga Pekan, ini disebabkan karena pengetahuan ibu balita yang kurang sehingga mereka tidak membawa anak mereka untuk diberi imunisasi MR. Tinggi atau rendahnya pendidikan seseorang akan berpengaruh pada hal penerimaan informasi kesehatan yang diberikan. Semakin tinggi pengetahuan seseorang seyogianya akan semakin mudah menerima informasi sehingga banyak pula informasi yang dimiliki (Notoatmodjo, 2010).

\section{KESIMPULAN}

Ada hubungan pengetahuan, sikap dan sumber informasai dengan rendahnya cakupan imunisasi MR (Measles dan Rubella) di Desa Simpang Tiga Pekan Kecamatan Perbaungan Kabupaten Serdang Bedagai.

\section{DAFTAR PUSTAKA}

Alimul, Aziz. 2011. Metode Penelitian Kebidanan dan Teknik analisa Data. Jakarta. Salemba Medika.

Arikunto, Surasmi. 2013. Prosedur Penelitian Suatu Pendekatan Praktik. Jakarta. Rineka Cipta.

Depkes RI, 2017. Imunisasi Measles Rubella Lindungi Kita. Medan.

Dinkes Sergai. 2018. Profil Kesehatan Kabupaten Serdang Bedagai 2017. Sergai.

Ditjen P2P, K. R., 2016. Petunjuk Teknis Kampanye Imunisasi Measles Rubella (MR). Jakarta: Kemenkes RI
Ditjen P2P, K. R., 2017. Petunjuk Teknis Kampanye Imunisasi Measles Rubella (MR). Jakarta: Kemenkes RI.

Hidayat. (2008). Pengantar Ilmu Kesehatan Anak. Salemba Medika Yogyakarta.

Hidayat, A.A.A., 2011. Metode Penelitian Kebidanan dan Teknik Analisa Data. Jakarta: Salemba Medika.

IDAI, 2017. Imunisasi Campak Rubella (Measles, Rubella).

Kemenkes RI. (2017). Ini Rencana Pelaksanaan 3 Vaksinasi Baru Untuk Lengkapi Imunisasi Dasar.

Kemenkes RI, 2016. Profil Kesehatan Indonesia $2015 . \quad$ Jakarta: Kementerian Kesehatan RI.

Kemenkes RI, (2013). Peraturan Menteri Kesehatan Republik Indonesia Nomor 42 Tahun 2013 tentang Penyelenggaraan Imunisasi. Jakarta: Kementerian Kesehatan RI.

McGee, P., 2013. Measles mumps. And rubella. Diversity and Equality in Health and Care.

Najah, L. 2017. Tingkat Pengetahuan Ibu Tentang Imunisasi Tambahan MR (Measles, Rubella) Pada Balita di Puskesmas Kotagede I Yogyakarta.

Notoatmodjo, Soekidjo. 2003. Ilmu Kesehatan Masyarakat. Jakarta : Rineka Cipta.

Notoatmodjo, Soekidjo. 2010. Metodologi Penelitian Kesehatan. Jakarta: Rineka Cipta.

Notoatmodjo. 2010. Kesehatan Masyarakat Ilmu dan Seni. Jakarta: Rineka Cipta. 